\title{
The Arabized and the Intruder in Al Muheet Dictionary by Al Fayrouzabadi
}

\author{
Dr. Shatha Jassim Hadi
}

Al-Iraqia University, College of Media, Iraq

Received: 11 Nov 2020; Received in revised form: 07 Dec 2020; Accepted: 13 Dec 2020; Available online: 19 Dec 2020 (C)2020 The Author(s). Published by Infogain Publication. This is an open access article under the CC BY license (https://creativecommons.org/licenses/by/4.0/).

\begin{abstract}
It is known to all of us that language is a system that is affected by time and space, and is subjected to the growth, development, death and extinction to which living organisms are exposed. And while people are suffering, the language is also struggling, so some words will migrate from one language or move to another, because some people move from one country to another.

Therefore, the presence of the arabized and the intruder in the language is a natural human phenomenon, as is the case with the meetings with people, their cooperation and experiences, and the exchange of interests and experiences between them. Because understanding language is the main means to achieve this goal, and it is self-evident that a person puts foreign words in a specific situation and differs from one case to another, so they are common in his language and mixed with it, so sometimes it is difficult to know their source.

Like other languages, the Arabic language suffers from the multitude of languages, because the Arabs before Islam met people from afar, but the scope of this meeting was limited and narrow because they lived on their own islands. This is affected by other countries and languages, and this deepens their pride in themselves and their language, so compared to the expansion after Islam, the pre-Islamic and post-Islam era had few Arabized and extraneous expressions, so Islam entered many countries from the people of open countries, and Islam entered many other countries. Types of life are transmitted to the Arabic environment, and the Arabic language is affected by a large crowd, so writers and poets must use foreign terms because these words are very common in actual use.

The influence of these languages varies with the different cultures and civilizations of the peoples of different countries, the length of the meeting, the length of time, the breadth of the field and the diversity of vision, the strength and usefulness of the language itself or religion or the difference in linguistic immunity resulting from ethnic immunity.

This problem is not only limited to borrowing, but also extends to the effects it leaves to predict the effect of this borrowing between languages, and appears in the elements of a language: in terms of its vocabulary, structure and methods, but scholars are not. Terminology and methodology focus on these effects. Because of its weakness, their research is limited to the phonemic and structural aspects of the vocabulary.
\end{abstract}

Keywords - Intruder, Al Muheet Dictionary, Arabic language.

\section{INTRODUCTION}

The main means of understanding between people is language, and language carries in its structure, expressions and content the life experience of the community in its past, and its future aspirations, whether on the level of interaction and nature, or at the level of interaction between the members themselves.

If the language is sounds formed in vocabulary, then there is no doubt that this life experience plays a role in creating ISSN: 2456-7620

https://dx.doi.org/10.22161/ijels.56.53 sounds and formulating vocabulary. Each language has its own character, framework, and interests, hence its orientation and richness, and we mean by orientation, its focus in creating vocabulary stemming from its life needs while it is in the process of Formation, life in the desert requires the creation of hundreds of expressions about the nature of the desert in its different states.

At the present time, the search for the Arab and the outsider has become a reality, because the phenomenon of 
acquiring Arabic and borrowed words in Arabic from foreign languages is one of the most important phenomena that have occurred in the Arabic language since ancient times. Arab linguists have been interested in this matter, and the study of this phenomenon has touched the potential of the language, As it shed light on its ability to understand the civilizational vocabulary and the scientific and technological institutions that are overwhelmed by the terms of our world at all times, this technique has taken a huge technological leap, and the expressing and intruder is considered one of the characteristics of Semitic languages, and each language has its own characteristics in sound, form, rules and semantic system.

The Arabic language was endowed by God by virtue of its association with the Holy Qur'an, and it carried a civilization spread all over the world. History has proven that the Islamic civilization appeared in different types: chemistry, medicine, engineering, philosophy ... etc., and it means those sciences based on terms that did not exist. In the Arabic language before the era of Arabization and translation, the mechanisms of translation and Arabization differ from one language to another, but rather from one linguistic level to another.

The Arabic language is an etymological language, and it is a practical aspect by which Arabic words can be identified from other words, and they can be converted into a pure Arabic language through derivation (Dinawi, 2004: 1-4).

\section{THE REASONS FOR CHOOSING THE RESEARCH TOPIC}

- To contribute to the study of Arabic expression through serious scientific research. The Arabic language is considered in this dictionary a phenomenon that deserves to be studied because it will reveal how Arabs deal with this phenomenon, especially in the dictionary.

- We choose (The dictionary of Al Muheet dictionary) as a material we used in this study because it has the following advantages: His interest in the words of Arab translators and his warm celebration of them indicates his eagerness to clarify the origins of the words. Therefore, based on the author's understanding of Persian, studying Arab translators in surrounding dictionaries is very useful, And a great scientific value because this is his first language, this allows him to attribute words to the source of the words and to indicate changes that have occurred in the words.

He has a wealth of information and extensive research: he has collected between his two covers the differential parts of the language drawn from (The Muhkam), (The Abab), and other dictionaries, covering all categories in total, up to 60 thousand articles.

- His inimitable way and his tight approach to controlling words, as he was not satisfied with controlling the pen, but rather controlling the words with the phrase for fear of correction and distortion.

\section{THE IMPORTANCE OF RESEARCH}

\section{(Al-Fayrouzabadi, 2009: 100-150)}

1. Arabization is an important linguistic problem, and its roots go back to ancient times, because Arab scholars have been interested in it since ancient times, and our two thousand refer to Arabized and extraneous terms in multiplying their public and private dictionaries, and the reasons for writing these terms are the Muslims 'interest in the Qur'an and their jealousy of it, and the attempts of Arab scholars to preserve The Arabic language and distinguishing the original from the outsider.

2. The importance of this study also stems from the fact that it is an applied study of the semantic field theory that was cited by Westerners, so that we can see its usefulness and the adjustments that must be made to be compatible with the nature of the Arabic language.

\section{RESEARCH AIMS}

The research aims to achieve the following objectives:

1. Observe the expressive words contained in the dictionary (Al Muheet dictionary), then determine their meanings accurately.

2. Putting the expressions in a combined and comprehensive form to prove that the language is a unit and a comprehensive structure, and we negate what is said about it: that they are separate elements.

3. Emphasizing one of the characteristics of the Arabic language, which is that the Arabic language is a language with a high capacity for acceptance and giving, and it is a flexible language that absorbs useful information that you find in other foreign languages for its development, development of linguistic wealth, expansion of the Arabic dictionary, and keeping pace with civilization development.

4. In general, providing comfort to researchers and language users, and helping them to arrive at the Arabic words and choose the appropriate expressions.

\section{LIMITS OF RESEARCH AND METHODOLOGY}

The Arabicized expressions are treated in Al Muheet dictionary of Fayrouzabadi as follows: 
1. Study the Arabized expressions contained in Al Muheet dictionary without distinguishing terms and other terms used, such as: (intruder) or (foreigner), then go to the books related to the Arab and the outsider, and find out the terms contained in these books, whether they are mentioned by Fayrouzabadi or not without mentioning Its collective language, or completely ignore it.

2. Restriction to the expressions that Fayrouzabadi stipulated as Arabicized.

3. The use the book Maarabat to explain the meaning of the expressions of Fayrouzabadi not mentioned, as well as the rooting for them.

4. Divide the words into semantic fields and arrange them according to their picture, regardless of the originality of their letters, or increase some other letters according to the alphabetical order of the first letter, the second letter, and the third.

As for the approach that we followed in this research, it is an approach that combines the descriptive approach and the comparative approach.

\section{RESEARCH PLAN}

Due to the nature of the research, it should be divided into six sections that include six semantic fields, preceded by the introduction and introduction, followed by the conclusion, and then indexes.

Introduction: It contains the title of the research, the reasons for choosing the topic, its importance, its objectives, and the research plan. Preface: It includes three points, namely

1. Definition of Fayrouzabadi.

2.The concept of the Arab and the outsider and the foreigner.

3. The main topic of this research, (The Arabized and the Intruder in Al Muheet Dictionary of Fayrouzabadi).

6.1 THE DEFINITION OF AL FAYROUZABADI, the scholar Majd al-Din Abu Taher Muhammad bin Ya'qub bin Muhammad bin Ibrahim bin Omar bin Abi Bakr bin Ahmed bin Mahmoud bin Idris bin Fadlallah bin Sheikh Abi Ishaq Ibrahim al-Shirazi, famous for our Mawlana Sheikh Majd al-Din al-Fayrouz Abadi al-Shirazi, the linguist Shafi'i al-Siddiqi, judge of The judges.

\subsection{DEFINITION IN LANGUAGE (RIDA, 2009: 1-10)}

\section{1- Arabized:}

An accusative noun from the verb Arabic expresses an expression. Its meanings are the rendering of an attribute, and the indication of becoming, such as our saying: stone clay, meaning: it became stone, or likened it to inertia, so we said: I defined the foreign word, meaning: I made it adjective to the Arabic word.
The foreigner is expressed as Arabic, and Arabized, all of this is for the sorrow that does not disclose anything, and in its logic is a foreigner ... and Arabized Arabs: a people of the non-Arabs entered the Arabs and spoke with their tongue, and they rubbed their bodies and were not explicit about them, so they became Arabs, not their origin.

\section{2-Intruder:}

The meanings of the linguistic origin (d. K. L) do not depart in all his statements from the fact that something is alien to something else, and foreign to it, which has no characteristics unless it is entered. Al-Khalil (The intruder: Whatever entered the property of a person from abroad. And so-and-so entered, as he entered, and entered into his mind or his mind ... and in it entered from emaciation ... And entered in color: mixing colors in color "( Al-Khalil 2003: 230).

Al-Asma'i said: The intrude is from pasture: what entered into the branches of trees, and prevented it from turning away from being grazed, and the intrude: the little bird. Because he is seeking refuge in every narrow hole of prey, and intrude: the corruption inside the human being of the mind or body (Abu Mansour, 2001: 276).

And the intruder is someone who intervenes in your affairs, and it is said: The sons of so-and-so in the sons of so-and-so are the intruders, that is, they belong with them and are not among them (Ibn Faris, 1979: 359).

The word "intruder": it was included in the words of the Arabs and not from it (Ibn Faris, 1986: 321).

\subsection{DEFINITION IN TERMINOLOGY (RIDA, 2009:}

\section{1-10)}

\section{1- Arabicizer}

It is the foreign pronunciation that the Arabs changed by adding, adding, or substituting. And it says in Al-Mizhar: "It is what the Arabs used of words placed for meanings in other than their languages."

From the above, it can be said that the Arabized word is the foreign word that accepted the standards of Arab speech.

\section{2- The intruders}

They are foreign words that entered the Arabic language without any change, such as oxygen and the phone. The intruder can be understood as a group of expressions and names that have nothing to do with the roots of the Arabic language, because their pronunciation is the same as the original language (Ibrahim, 2004: 16).

\section{THE ARABICIZER AND THE INTRUDER IN THE ARABIC LANGUAGE}

The traditionalists of scholars have classified the foreign expressions introduced into the Arabic language into two parts: the Arab and the al-Dakhil, and relied in this 
classification on history, so they said about the expressions that were introduced in the era of protest by Arabs who claim that they are Arabized or Arabized, and the borrowing process According to this traditional historical consideration, it is an expression.

And they said about the terms that were borrowed after the era of protest that they are extraneous, so what is expressed on this basis is that word that the Arabs borrowed from other nation, in the era of protest by language and used it in their speech, whether it comes on the weights of the Arabic language or not. Sundus, ginger, bricks, squirrels, ... these words were mentioned by the Arabs during the era of protest.

The intruder is that term that Arabic borrowed from another language at a stage after the era of protest, later than the era of the sincere Arabs who invoke their words, whether this term was appropriate to their weights of speech or not as well, since the pure Arabs did not utter it. It is in Greek (Lykima) meaning an explosion that entered the Arabic language by Turkish, as well as the word (customs), which was entered from Latin by Turkish and its origin is (Commercium) and extends this stage during which the borrowed words are considered to be extraneous to our days. Among the names of inventors, and examples of recent extraneous words: telephone, and television.

However, some have divided the intruder, in turn, by a historical division, so if the entry was made by the later in the ages of protest, then it is from the generation. As for those who were late, then what they entered is considered new, and this consideration was confirmed by Dr. Hassan Zaza, where he says " The foreign language used by the Arabs who invoke their words is considered to be Arab, even if it is not in terms of its construction and its morphological weight, which is included in the structures of the words of the Arabs. "It is this definition that we prefer and prefer."

However, many linguists consider the classification on this historical basis unfair to the right of successive generations of Arabs after the ages of protest, so how could those who lived after the period of protest had the right to express whatever foreign words they wanted, and consider them as shameless Arabic, then deprive ourselves of An analogy to what those Arabs did, and we call what we may have to introduce into our language an outsider, a generator, or an updater, and we look at it as our view of the strange stranger who has no right to enter the Arabic language, especially since all living languages in the world borrow from each other, and are not considered This is defective, and she makes what she borrowed in her crucible of her language, and considers it as original in her words.
Hence, we can adopt another differentiation that is based on the formula and the structure, which is the weight chosen by Dr. Samih Abu Mughali, saying: "I am inclined towards an opinion that I consider more accurate and realistic, which is the differentiation on the basis of formula and structure."

This is a basis adopted by the modernists in differentiating between the Arabic translator and the intruder, if they saw that the intruder "applies in its current linguistic meaning to foreign expressions that the Arabs have not changed and kept in their original form in their language, or on their foreign construction at least". Which the Arabs changed and attached to their buildings".

In this regard, Dr. Ibrahim Anis says: "The Arabic word, which was commonly used by the ancient Arabs, took the Arabic fabric and revisited its edges, changed some of its letters, and changed the position of the accent thereof, until it became similar to the Arabic words, and that is what the Arabic scholars called Later in the Arab, as for other foreign words that remained in their original form, they are few in number. They have remained few in frequency and circulation. The foreigner called them the intruder, as if I want to exclude them from the original Arabic words.

It is natural for the intruder to be much less than the Arab, and less common than him, because if the intruder became popular on the tongues and his friendliness was to change his construction from overuse, he was no longer an intruder, but rather became one of the Arabized ones. In fact, many scholars did not differentiate between the Arabized and the Intruder, and used them in one sense, as did "Shihab al-Din al-Khafaji" in Shifa'a Al-Ghaleel, and "Al-Suyuti" in Al-Muzhar and others.

Based on the above, we try to separate these two phenomena (the Arabized and the intruder), for more clarification (Al-Fayrouzabadi, 2009: 880-899):

\subsection{THE ARABIZED, ITS FOUNDATIONS AND METHODS (AL-FAYROUZABADI, 2009: 800-900)}

The Arabized was alone with measures that made him his own name, so he was no longer called an outsider, although he remained moral, original and practical from his group.

Al-Suyuti gives two definitions of the Arab and says: "It is what the Arabs used from the words that put glosses in a different language" (Abd al-Rahman, 1998: 268), and he says: "Arabization of the foreign name is that the Arabs utter it on its curriculum. (Ibn Manzur, 1999: 115-116).

The definitions are all in two points, a foreign origin and an Arabic pronunciation, dyeing the word with an Arabic tone when it is transferred from a foreign language, or transferring the foreign word and applying it to the Arabic curriculum and its structures. 
And we add an important note here, which is that the Arabic word may not need to be modified, because its pronunciation is an Arabic word and it has a similar expression in Arabic, but in a different connotation. In this sense, it is an extraneous one, and an example of that is: (Jasmine), which means dice in Arabic, Persian, while there is the word (Jasmine) in Arabic, but it indicates the pattern put forward to camel's back.

Al-Suyuti narrates from "Abu Hayyan" a word that divides foreign names into three sections, and says: "Foreign names are divided into three parts: a division changed by the Arabs and attached to their words. It changed it and did not attach it to her words, so what is considered in the section that preceded it is not considered in it, about: a brick and a tafsir, and a portion that they left unchanged, so what they did not attach to their speech constructs did not return from them, and what they attached to them was counted from them, the first example: Khurasan does not prove effective And an example of the second: "Khorram is attached to peace, and your turmeric is attached to Persian, meaning that the foreign expressions that the Arabs added to the weights of their language, whether they changed it or not, are considered from the Arabists. As for what did not enter into the weights of their language, whether they changed it or not, it remained far from the language Intruders to it, and accordingly, we can determine the foundations of Arabization, which "Saadi Dinawi" referred to in his dictionary as follows:

\subsection{WORD STRUCTURE OR CONSTRUCTION}

If its structure is similar to the structure of the Arabic word, it is accepted without modification, Sibawayh says: "Know that from what they change from the foreign letters, what is not from their letters at all, they may have joined them by building their words, and perhaps they did not follow it. Attach him to Salhab, and a Dinar to attach him to Dimas "(Sebawayh, 1988: 303).

But if it is not similar to the structure of the Arabic word, then they make an amendment to the structure: "Perhaps they changed its status from its state in the foreign language with their attachment to Arabic other than the Arabic letters and changed the movement. Rather, he invited them to that because the foreign language is altered by its entry into Arabic by changing its letters, so this change prompted them to switch and change the movement.

Change in letters and movements Sibawayh continues, saying, "Perhaps they deleted the same as they delete in the addition, and they increase as they add to what they inform the building and what they do not want to build, and that is about bricks, Ibresim, Ismail, and Kahraman, and they did that with what was attached to their building and what was not added by change, replacement, increase and deletion. They left the name unchanged if its letters were from their letters (had to be built or not) towards Khurasan, Kharram, and Curcuma, and perhaps they changed the letter that is not from their letters and did not change it from its construction towards Verand.

\subsection{SUBSTITUTION OF LETTERS IN ARABICIZED PERSIAN WORDS (AL-FAYROUZABADI, 2009: 800-900)}

This is because they switch from the letter between the $(\mathrm{K})$ and the $(\mathrm{G})$. The $(\mathrm{G})$ is due to its proximity to it and it was not interchanged because it is not one of their letters (i.e. the Arabs), towards the sock.

And they may have replaced the previous letter with the $(\mathrm{K})$, because it is also close, so some of them said: gharbuq and gerbq (meaning they replace it with (k) also)

And they switch from the letter that is between the (y) and the $(\mathrm{K})$, then the wafa, towards the hotel and the hotel, and they may change the (B) (meaning perhaps they replace it with the (y)), because they are all close, so some of them said: the brad, so the allowance is steady in every letter that is not one of their letters.

Change the movement as in Zor and Ashub, they say falsified and blameless.

It does not expel the allowance, so the letter that is from the Arabic letters is towards trousers (it was Sein Shina), so they switched from the Seine towards it in a whisper and slipping from between the folds.

Arabization is a word whose connotations have converged with ancient linguists and modernists alike, and everything they came up with is almost revolving in one orbit, which is every foreign word that entered Arabic in the past or in modern times, provided that we are subject to the standards of Arabic and its structures.

The linguists did not leave the matter randomly, rather they set standards that prepared the original in that, as they print the Arabic expression with the Arabic character, by making some modifications to it, which render it Arabic, and these modifications may be morphological, so the word is reconfigured on an Arabic weight, and it may be phonemic by choosing the closest Arabic sounds In place of the foreign language, in addition to the slurring, media, or heart, this is done in accordance with the laws of the phonemic coalition and what is required by the nature of the Arabic pronunciation.

The Arabs may leave the Arabized name as it is in its language, if its letters are one of their letters, whether it is on a building of their speech structures or not, such as (Khurasan), and they can attach the Arabized name to their 
buildings, such as (a dinar and a penny). P (penny) Arabized Drum.

And (dinar) is an Arabicized Dinar, meaning the Sharia brought it, and the Dinaric syrup is relative to Ibn Dinar Al Hakeem Mawlid.

And they may change the letter that is not from the Arabic letters, such as: Fernand and Ajar. (brick) is a clay dish, roasted brick, one is a brick. And (Farand, Brand), which is the sword wreath, the essence of the sword in which it runs and its methods, and its ruddha, "Hawjum," which is the red roses, a garment of mushy silk, the love of pomegranate, from the Persian: "Barnd" The Prophet - may God's prayers and peace be upon him heard from Salman the word "trench", so you will explain it about its meaning, so he knew that it was "a pit surrounding a fortress or a city, which was collected by trenches from the Persian:"Kendah "meaning the dug, and the $\mathrm{H}$ sound turned $\mathrm{K}$ sound in Arabization, and the word is shared by a number of Languages: Turkish, Kurdish, Syriac, as well as Arabic ».

(Thus, the Prophet - may God bless him and grant him peace - accepted it, and began to use it, and he derived (trench) from it, so the raid was called the Battle of the Trench.

After these vocabulary is merged into the original speech of the Arabs, how can we distinguish the Arabized expressions from the words of the original poem?

Linguists have referred to several methods of investigating and detecting the Arabic word, the most important of which are:

1- The phonemic method: If there are voices in the word that the Arabic does not combine in its speech, this indicates that it is expressive, such as the meeting of the gym and the $\mathrm{K}$ sound, like the word (manganik). And (Mannik) "is an ancient machine from the fortressramming machine, with which it used to throw huge stones on the walls and demolish them. From Persian: (From Nik), meaning I am what, good, it is" what is best for me. "

Or she is from you, gennik, "any good method for war," or she is from you, "nickname," meaning good height.

2- The Sufi scale: If the word is on other than Arab buildings, this indicates its grandeur, such as: (Khurasan).

And (Khurasan): "The knowledge of Hafid from Noah's grandson, peace be upon him, just as Rum, Persia, and Kerman open the kaf as well, then it became a flag from these well-known countries, which are below the river from the countries of the East, and their mothers are Nishapur, Herat, Meru and Balah, with their aspects, quarters and their additives."

3- Derivation: If the word does not have an etymological origin, this indicates its grandeur, such as (Tannour), which is the name of a foreigner in origin, so his Arab vehicle is, and has become an Arab based on the construction of an animal.

And (Tannour): «a bakery consisting of a deleted cylinder lined with a letter or another, gathered on skirts, it was said from Persian, and it was said from the Syriac" Tanouro ":" the house of fire "in which it is baked, or the kanun, and it was said from the Hebrew:" the smoke of fire "It seems that it is one of the ancient Semitic words common to its languages.

4- Sociology: If Arabic and non-Arabic are in conflict with one word, he will look at its meaning. If it indicates what is specific to the Arabs, it is Arabic, and if it indicates something specific to non-Arabs, then it is Arabized.

5- Comparison: If Arabic and others disagree with a word, and the previous method does not enable us to discern its origin, the linguist resort to comparing Arabic with its Semitic sisters. It is a Latin word, which does not exist in the Arabic sisters from the Semitic languages.

The crisis of the Arabic language in the vocabulary is getting worse day by day, because of what the Western civilization throws us every day from dozens of names related to science, arts, literature, machines, inventions, industrial and pharmaceutical preparations, and others. Specific to the issue of Arabization, and they differed in that, so they formed different sects of them: the extremists who argue that foreign words must be Arabized as agreed, and among them the fanatics who see the impermissibility of Arabization. Among them are the moderates Those who argue that it is permissible to use Arabization to fill the need for Arabic vocabulary, provided that this Arabizer does not spoil the origins of the language or deviate with it from its familiar ways.

Most of the linguists, therefore, see that Arabization is a necessity in most cases, and if the necessity does not arise, then there is no need for Arabization.

6. Al-Dakhil in the Arabic Language (Al-Fayrouzabadi, 2009: 890-899)

The phenomenon of the intruder in the Arabic language is ancient and renewed, dating back to the era of the first Arabic, the time of ignorance. It is accompanied by another phenomenon, which is the colloquial language that has kept pace with the classical language and runs alongside it throughout the ages, and the two phenomena of the intruder have coincided with the global, and went side by side with the classical (Shihab Religion, 1998: 3). Arab scholars and others took great care of the Intruder, so they gathered his words and rooted their origins, in order to reach the path from which they entered, and the time in which they crossed, and many books specialized in the Intruder appeared, including the book "Al-Mizhar" by Al- 
Suyuti, which was devoted to him many chapters, as well as "Ibn Qutaiba in the book "Literature of the Writer", and so on.

Books have also appeared concerned with the colloquial and everyday speech of people, referring to their doubling of the correct formulas from the melodic and Arabic from the Intruder, including the book "Colloquial Melody" by Al-Zubaidi, and the book "The Tongue Calendar" by Ibn Al-Jawzi, and others. Shifa'a al-Ghaleel in the words of the Arabs from the intruder "to collect the two phenomena of the intruder and colloquial in his era, providing the Arab library with a double-subject, branched-out, multi-useful work, and from here it gained value in the Arab library, so that it became the most reliable source and the purest source for researchers in the intruder and colloquial, as well as auditors. Interested in countries 'language and speech.

The book "Shifa'a Al Ghaleel" provides a great service to researchers and scholars of colloquialism and the Intruder.

1- The first is that the intruder knew Arabic from its early ages, as I knew it in the later and present eras, although the quantity is greater and the type is more recently.

2- The second is that the colloquial or folk language was known by the Arab community at a time when it most likely knew classical Arabic.

It can be said that horses and colloquials exist in every age, dictated by the nature of social life, and our age is like antiquity in which there are many intruders.

Our era is not different from previous eras, and there is no fear for Arabic of decay and atrophy, and the book "Shifa'a Al Ghaleel" is a picture of the existence of this intruder.

It was mentioned in the surrounding dictionary that "the intruder" is every word that was entered into the words of the Arabs, and not from it, and the letter between the narrator and the thousand foundation, and "entered" is a motive: they belong with them and are not among them.

The linguistic origin of the Intruder helps us to define the linguistic term Intruder, with its later connotation, which is the introduction of the foreign word into Arabic in its form and pronunciation without change, such as: (Abzim, fax, video).

In (Abzim), for example, it is an iron lug at the end of the belt, the tongue of the buttonhole into which the belt hole is inserted, a lock, a spur, gathered on "buckles", from Persian, and it was said from the Greek.

Such expressions are intended when the foreign expression becomes difficult to Arabize, and in this case the scholars have required that the identity of the intruder be preserved, so that it remains as it is without any of the characteristics of Arabic phonetically or morally falling to him, because that may change the connotation of the word, so it cannot then Belonging to Arab and foreign.

The intruder is called the foreign word that is not subject to the standards of Arabic and its structures, that is, what is not carried on Arab buildings, as for the Arab, it is what is made of the word foreigner with an Arab weight.

Among the extraneous nouns is what is difficult to uncover its word because its structure is appropriate for the structure of Arabic speech, its letters free from the stranger, and the harmony of these letters with the Arabic tone, but there is an intruder that leaves no room for ambiguity, either for its structure or for the letters that converge with it.

1- Among the formulas that deny the Arabic structure (Ibrism), such weight is missing in the Arabic noun structures.

And (erism) is the silk found in nature in the form of a thread that a silkworm weaves around itself. It turns a cocoon from the Persian "aprichem", that is, that which goes as a bunch, and perhaps the closest to being from the Greek "prsinos", meaning other silk. Among them is that it should be pentagonal and quadruple, naked from the letters of the zalaqah, which are: (Baa, Raa, Fa, M, Llam, and Noon sounds), so when it is Arabic, there must be something in it: Towards (Quarsgil) and (Qurtab) (Houria, 2016: 94).

From the formulas that deny the coalition of letters in Arabic:

- That the end of it is a letter zai with the number of grammar (muhanned), because that is not in an Arabic word.

- That the Sadi and the gym meet in it, towards (mace) and (gypsum).

- That the gym and the stand meet in it, towards (the catapult).

- That the Jim and Ta meet in it without the letter Z, such as (Jibat).

Through all of the above, we can reach a number of important results, namely:

1- There is no objection to Arabization if it is urgently needed, and whenever it is not possible to find an Arabic word that corresponds to the foreign, or is useful for its meaning. Also, there is no objection to resorting to the intruder whenever the foreign expression is difficult to Arabize, provided that we do not denote any of the characteristics of Arabic phonetically or morally.

2- Standing on the Arabic language confirms the breadth, flexibility and richness of Arabic, and allows for the continuity of the characteristics of Arabic, on top of which is the derivation, then it is evidence of the ability of the Arabic language to represent and imbibe neighboring 
cultures, and to reproduce its linguistic stock according to its contexts and linguistic systems.

3- Resorting to the Arabized and the Intruder emphasizes the civilizational communication between Arabs and neighboring nations, which is represented in the commercial, political, economic and cultural relations, which are afflicted by vocabulary of Persian, Indian or Greek origin.

4- Believing in the richness of the Arabic language that God Almighty honored in the Noble Qur'an, and in recognition that the Arab nation in its endeavor for progress and contemporary is not cut off from a great legacy of creative scientific endowment, and in order to preserve, develop and enrich Arabic to accommodate everything new, priority must be given to Arabic expressions whenever possible, with Asylum when needed to the Arabizer and the intruder

\section{THE OPINIONS OF SCHOLARS AND THEIR POSITION ON THE ARABIZED IN THE HOLY QUR'AN.}

Scholars have different opinions on this issue, between those who are against it, those who say that they should fall into place, and the average between them. 1- Opinions and evidence of those who say it is forbidden (Hammouda, 1989: 50-250)

Imam Al-Suyuti, Ibn Jarir al-Tabari, Abu Ubaidah, al-Qadi $\mathrm{Abu}$ Bakr and Ibn Faris were of the view that the Arab ruler did not fall into the Noble Qur'an, relying on this to the Almighty's saying

"Surely We have revealed it-- an Arabic Quran-- that you may understand".(Joseph:

And the Almighty said: "If We had made it a foreign Qur'an, they would have said, had it not been detailed in its verses, non-Arab and Arab, say it is to those who believe in guidance and healing".( Fusilat:4)

Imam Al-Shafi'i detailed the matter and responded to the opponents, saying:

"And from intercourse with the knowledge of the Book of God: the knowledge that all of the Book of God was only revealed by the tongue of the Arabs ... and he spoke about knowledge, if he seized some of what he spoke about it, it would be better to hold it and be closer to safety, God willing. Arabic and non-Arab, and the Qur'an indicates that there is nothing in the Book of God except with the Perhaps the one who said: language of Arabs".

That there is in the Qur'an other than the tongue of the Arabs and that was accepted by it: He went to the fact that it is a special part of the Qur'an that some Arabs are ignorant of. So that no one who knows him is present in it.
Imam Al-Shafi'i (may God be pleased with him) conveys what the non-Arabs uttered from the tongue of the Arabs on learning and says:

If someone said: We may find among the non-Arabs who utter something from the tongue of the Arabs, then that is likely what you described from them who learned it, and if it was not from them that he learned there is no uttering except a little of it, and whoever utters a little of it then he follows the Arabs in it. It carries on the compatibility or the contemplation, and this is what Imam Al-Shafi' $i$ confirmed in his message, where he says: "We do not deny that if the word was learned or uttered a subject that corresponds to the language of the non-Arabs or some of them a little, from the tongue of the Arabs as agreed. A few of the foreign tongues differing in most of her words with the couple of her homes, the difference of her tongue, and the bonds between her and those whose tongue part of her agreed with her"(Muhammad, 2009: 157).

And after Imam Al-Shafi'i detailed the issue, he brought evidence and evidence for his opinion, and said: "If someone said: What is the argument that the Book of God is purely in the language of the Arabs, and no one else mixes it with it? Then the argument in it is the Book of God, God said "And We sent not a Messenger except with the language of his people". (Ibrahim : 4).

If someone said: Because the messengers before Muhammad were sent to their own people, and that Muhammad was sent to all people, it may be possible that he was sent by the tongue of his own people in particular, and all people would have to learn his tongue and what they were able to do, and it is possible that he was sent with their tongues: is there any evidence that he was $\mathrm{He}$ sent the tongue of his people, especially without the tongues of non-Arabs? If the tongues are different from what some of them do not understand from one another, then some of them must be according to one another, and the merit of the tongue followed by the follower, and the people most favored in the tongue, from his tongue is the tongue of the Prophet, and it is not permissible and God knows best that the people of his tongue follow the people of a tongue other than his In one letter, but every tongue follows its tongue, and all people of a religion before it must follow his religion, and God has explained that in a different verse from his book (Muhammad, 2010: 161):

God Almighty said "And truly, this is a revelation from the Lord of the creatures, which the trustworthy Ruh (Jibril) has brought down upon your heart that you may be (one) of the warners, in the plain Arabic language".(Al-Shuaraa: 192-195)

And God Almighty also said " Thus have We sent this down - an arabic Qur'an". (Al Raad: 37). And God 
Almighty said "We also revealed to you an Arabic Quran to warn the Umm al-Qura (Makkah )and those around it"(Ash-Shura: 7). And God Almighty said "Verily We have made it an Arabic Qur'an that you may understand"(Al-Zukhruf: 1-3). And God Almighty said "An Arabic Quran without any crookedness, that they may guard (against evil)". (Az-Zumar: 28).

Imam Al-Shafi'i said after that: He established his argument that his book is Arabic in every verse we mentioned, then confirmed that by denying it - his praise of every tongue other than the tongue of the Arabs, in two verses of his book:

And God Almighty said "And certainly We know that they say: Only a mortal teaches him. The tongue of him whom they reproach is barbarous, and this is clear Arabic tongue".(An-Nahl: 103). And God Almighty said "And if We had made it a Quran in a foreign tongue, they would certainly have said: Why have not its communications been made clear? What! a foreign (tongue) and an Arabian!". (Fusilat:44).

Imam Al-Shafi'i said: He made known to us His grace by the stature that He bestowed upon us, so He said "Verily, there has come unto you a Messenger from among yourselves. It grieves him that you should receive any injury or difficulty. He is anxious for you, for the believers - he is full of pity, kind and merciful".(At-Tawbah: 128). To the last of the evidence and arguments mentioned by Imam Al-Shafi'i from the Arabic of the Noble Qur'an and its absence of any foreign term. And if any foreign expression occurs in it, then it is by way of consensus or contemplation, as was described in detail above.

On the same path, Ibn Jarir and al-Tabari followed, and presented to respond to the violators and nullify their claim, that there are words in the Qur'an of non-Arab origin, with a directive of what was narrated from the Companions and Taabi'een regarding the ratio of words from the Qur'an to foreign languages that deviate from the validity of inference, and this is what held He has a special chapter in the introduction to his interpretation, after he inferred Arabic terms for the Noble Qur'an, in a way that does not deviate from the reasoning of Imam al-Shafi' $i$ (may God be pleased with him). Rather, he mentioned that in the language of non-Arabs, he compels him to agree, and he holds a chapter for that entitled: "The saying in the statement about the letters in which the expressions of the Arabs and other expressions of some races of nations agreed." He says:

We did not condemn the fact that there is some agreement in the speech in which the words of all the different races of the different tongues agree in one sense..also we have found much agreement in what we have learned from the different tongues, such as the dirham, the dinar, the medicine, the pen, the stationery and so on, which is difficult to count, and whose enumeration is complete. "(Al-Tabari (2005: 15).

At the end of the chapter, he says: "We have demonstrated the correctness of the saying sufficiently. That God Almighty has revealed all the Qur'an in the language of the Arabs and excluding others from the tongues of all the races of nations, and on the corruption of the saying of those who claim that it is not in the language of the Arabs and their languages" (Abu Ubaidah, 1981: 17).

Abu Ubaidah Al-Nkir emphasized that those who claimed that the Qur'an was from a non-Arabic one, so he said: "The Qur'an was only revealed in a clear Arabic tongue. ). It carries the foreign words in the Qur'an for compatibility in saying: "The term may agree and approximate it, and their meanings are one, and one of them in Arabic and the other in Persian or other."

Ibn Faris said: "There is nothing in the Book of God, the glorious praise of which is not in the language of the Arabs, and the saying is what Abu Ubaidah said, and that if the Qur'an had something in it other than the language of the Arabs, the illusion would be delusional that the Arabs were unable to do something similar because it came in languages that they do not know and that is what it contains ".

\subsection{OPINIONS OF THOSE WHO SAY THAT IT IS PERMISSIBLE FOR THE ARABS TO FALL INTO THE NOBLE QUR'AN (HAMMOUDA, 1989: 50-250)}

The second group argued that it is permissible for the Arabs to fall into the Noble Qur'an, including Abu Ubayd al-Qasim bin Salam, al-Khoyi, Ibn al-Naqib, al-Shawkani and others, and their evidence is the following (Sulayman and al-Toufi, 2012: 409):

1 - What was narrated on the authority of Ibn Abbas, Mujahid, Ibn Ikrimah, Ataa and other scholars, that they said in many letters that they are in the languages of the non-Arabs. Al-Sirat, Al-Qastas and Al-Firdaws are in Rumi.

Mishkat and Kaflin, it is said that she is in Abyssinia, and this is the view of Abu Ubayd, who attributed it to scholars among the jurists (Al-Jawaliqi, 1990: 92).

2 - What the grammarians have agreed upon prohibiting many of the names found in the Holy Qur'an being used by the native and the foreigner, such as Abraham, for example, and if it is agreed upon the occurrence of flags, there is no objection to the occurrence of races (Abd alJalil, 1981: 205).

3 - What they mentioned about the wisdom of the Arabization, that the Noble Qur'an contained the sciences of the first two and the others, and foretold everything, so 
it is imperative that the reference to the types of languages and tongues fall into it, in order to be surrounded by everything.

4 - This is what Ibn al-Naqib stated, saying: "One of the characteristics of the Qur'an over all the revealed books of God is that it was revealed in the language of the people it was revealed to them, and nothing was revealed in it in the language of others. ".

\subsection{THE AVERAGE OPINION BETWEEN PROHIBITION AND PERMISSIBILITY (HAMMOUDA, 1989: 50 - 250)}

The third group: It is the opinion of Abu Ubayd Al-Qasim bin Salam, who says: "The correct view in my opinion is that there is a doctrine in which all the two sayings are based, because these letters have foreign origins, as the jurists said, but they occurred to the Arabs, so they translated them in their tongues or converted them from non-Arabic words into their own words, and then the Qur'an was revealed. These letters have been mixed with the words of the Arabs, so whoever says they are Arabic is true, and whoever says they are foreign, then he is honest. He said: Rather, we interpreted this so that no one would take precedence over the jurists and attribute them to ignorance, and make a delusion upon them that they embarked on the Book of God, the Exalted, the Exalted, the Exalted, in a way other than what God Almighty wanted.

They were more knowledgeable about interpretation, and more venerated of the Qur'an (Abu Al-Hussein, 2007: 33).

\section{CONCLUSION}

Several conclusions have been revealed, including that the Arabic language suffers from the abundance of languages like other languages because the Arabs before Islam met people from afar, but the scope of this meeting was limited and narrow because they lived on their own islands. This is influenced by other countries and languages, and this deepens their pride in themselves and their language, so compared to the post-Islamic expansion, the pre-Islamic and post-Islamic era has few Arabized and extraneous expressions. And that the Arabic language is a language with a high capacity for acceptance and giving, and it is a flexible language that absorbs the useful information that you find in other foreign languages for its development.

On the other hand, many examples of the Arab and the intruder in the Arabic language have been dealt with and know what they are, in addition to the opinions of scholars regarding the authenticity of the Arabic language and the absence of an intruder in the language of the Noble Qur'an who has honored the Arabic language and increased its prestige, aesthetics, its importance and its highness, and even suffices it with pride that it is the language of the people of Paradise.

\section{REFERENCES}

[1] Ibrahim Anees and others, Al-Waseet Lexicon, edited by: Zuhair Abdul Mohsen Sultan, Al-Risala Foundation, Beirut, 2004.

[2] Ibn Faris, The Standards of Language, edited by Abd alSalam Haroun, Dar Al-Jeel, Beirut, 1979.

[3] Ibn Manzur, Lisan Al Arab, House of Revival of Arab Heritage, Beirut, C9, 1999.

[4] Abu Al-Hussein Ahmad bin Faris bin Zakaria, the companion on thejurisprudence of the Arabic language and its issues and the Sunnah of the Arabs in its speech cartoon, Dar Al-Kutub Al-Ilmiyya, Beirut, 2007.

[5] Abu Mansour Al-Azhari, Tahdheeb Al-Linguistics, edited by: Muhammad Awad Mireb, House of Revival of the Arab Heritage, Beirut, 1st Edition, C7, 2001.

[6] Ahmed bin Faris bin Zakaria al-Qazwini al-Razi, Majlis alLugha by Ibn Faris, edited by: Zuhair Abdul-Mohsen Sultan, Foundation for Resalah, Beirut, Edition 2, Part 2, 1986.

[7] Jihad Reda, "The Arabic Language and Contemporary Challenges, Between The Arabized and The Truder", Jerash Cultural Magazine, Jerash National University, Jordan, Issue 11, 2009.

[8] Houria Madan, The Role of Derivation in Establishing Terms (The Glossary of Electronic Computing Terms as a Model), Dar Al-Kotob Al-Academia, Beirut, 1st Edition, 2016.

[9] Al-Khalil Bin Ahmad Al-Farahidi, Kitab Al-Ain, Dar AlKutub Al-Ilmiyya, Beirut, Part 4, 2003.

[10] Dr. Taher Suleiman Hammouda, Jalal al-Din al-Suyuti, his time, life and effects, and his efforts in the linguistic lesson (I. The Islamic Office, Beirut: 1989 AD).

[11] Al-Zarkashi, the proof in the sciences of the Qur'an, edited by: Dr. Youssef Al-Marashli, House of Knowledge, Beirut, C1, 1990.

[12] Saad Dennawi, The Detailed Dictionary of Al-Maarab and Al-Dakhil, Dar Al-Kotob Al-Alami, Beirut, Lebanon, Edition 1, 2004, p. 4.

[13] Suleiman bin Abd al-Qawi and al-Toufi al-Sarsari alHanbali, a brief explanation of al-Rawda in Usul al-Fiqh (a brief explanation of Rawdat al-Nazir and Jannat al-Mazhar by Ibn Qudamah al-Maqdisi), Dar al-Kutub al-'Ilmiyya, Beirut, 2012.

[14] Sibawayh, The Book (Kitab Sibawayh), Haqeeq: Abd alSalam Muhammad Harun, Al-Khanji Library, Cairo, 3rd Edition, C3, 1988.

[15] Shihab Al-Din Al-Khafaji, Healing Al-Ghaleel in the Speech of the Arabs from the Intruder, Al-Haram AlHusseini Great Commercial Library, Egypt, 1st Edition, 1952.

[16] Shihab Al-Din Al-Khafaji, The Healing of Al-Ghaleel in the Words of the Arabs from the Intruder, Dar Al-Kutub Al-Ilmiyya, Beirut, 1998. 
[17] Al-Tabari, Jami al-Bayan on the Interpretation of Ay alQur'an, edited by: Ahmad and Mahmoud Shaker, Dar alMaarif, Egypt, Part 1, 2005.

[18] Abd al-Rahman Jalal al-Din al-Suyuti, Al-Muzhar in Language Sciences and its Types, Dar Al-Turath, Cairo, C1, 1998.

[19] Majd Al-Din Muhammad Bin Yàqub Al-Fayrouz Abadi, Al Muheet Dictionary, seized and documented by: Youssef Al-Sheikh Muhammad Al-Buqai, Dar AlFikr for Printing, Publishing and Distribution, Beirut, Lebanon 1429-1421 AH 2009AD.

[20] Muhammad ibn Idris al-Shafi'i, the interpretation of Imam al-Shafi'i, Dar al-Kutub al-Ilmiyya, Beirut, 1st Edition, 2009.

[21] Muhammad Yusuf, Imam Al-Suyuti and his efforts in the sciences of the Qur'an, Dar Al-Maktabi Printing, Publishing and Al-Tawzi, Damascus, 2001.

[22] Hashem Yahya Al-Mallah, Islamic Civilization and Future Prospects, Dar Al-Kutub Al-Ilmiyya, Beirut, 2010. 